\title{
The Dark Side of Nation-States: Ethnic Cleansing in Modern Europe
}

\author{
by Philipp Ther \\ War and Genocide Series No. 19 \\ New York: Berghahn Books, 2016 \\ ISBN 978-1-78533-195-4 \\ Softcover $\$ 40.17,281$ pp.
}

\section{Reviewed by Johanne Sanschagrin \\ Office of the Auditor General of Canada}

The Dark Side of Nation-States looks at ethnic cleansing in Europe through the lens of nationalism and nationalisms. The author of the book, Philipp Ther, is a professor of Central European History at the University of Vienna, who has written and edited previous books on recent European history and on ethnic cleansing. This book, number 19 in a series called "War and Genocide," was first published in German in 2014. This is not a new book. It is historical rather than journalistic, even though its findings resonate through current events and even breaking news in 2017.

Many commentators and historians use the terms genocide and ethnic cleansing interchangeably, but Ther contends right from the start that they are not equivalent. Genocides aim to completely eliminate a population through mass killing, while ethnic cleansings intend to remove an ethnic group systematically from a given area. This does not mean that ethnic cleansings are not violent; on the contrary, they can be as deadly, but the intent is different. Ther's book does not focus on the violence and the human suffering; rather, it looks at the mechanics and the beliefs underlying the perpetration of ethnic cleansing.

The main thesis of the book is that ethnic cleansings in Europe are closely linked to nationalism, but these are nationalisms in a very narrow sense, associated with a desirability to be nationally homogeneous, which was an ideal in much of Europe in the 20th century. After the breakup of the European empires and formation of the newly formed countries, ethnic homogeneity was perceived as a key feature of state cohesiveness. The (continuing) presence of minority populations within countries was then seen as problematic, making it necessary to either expel them from the territory or to make them "invisible" through assimilation. The question remains why the notion of nationalism became so narrow in Europe and its former colonies, and why the love of nation became more important than regard for its parts. One might also wonder why and how ethnic homogeneity remains a powerful force today. Although the book does not answer these questions, it guides us through the complexities of recent European history and how the ideal of ethnic homogeneity has embedded itself and provoked conflicts through out the last century or so.

In his first chapter, Ther examines the preconditions to ethnic cleansing. One of them is the assumption that a nation-state must identify itself with an ethnically homogeneous population. From this utopian idea emerges the belief that ethnic minorities are an obstruction to the development of nation-states. The consequences of these ideas have been troubling when legitimized by international authorities such as the League of Nations and supported by national censuses that recorded people according to rigid categories a priori - that is, through demography to serve the purposes of nationalism. History offers many examples of European states that succumbed to the temptation to use censuses to justify the expulsion of populations from their territories or to obtain territories from other nations.

The core of the book, from chapters 2 to 5 , focuses on four periods of ethnic cleansing identified by Ther. The first period, from 1912 to 1925, is defined by internationally sanctioned population exchanges. Population 
exchanges were seen as a reasonable approach to pre-empting future conflicts between states and to consolidating nation-state order. From the Balkan Wars through the mass deportations surrounding WWI, and to the postwar migrations after the collapse of Tsarist Russia, the authorities referred also to ethno-logical arguments in order to remove populations from states and determine to which countries disputed territories would be assigned.

The second period corresponds to the German hegemony (1938 to 1944), when mass deportations in the millions took place. The distinction between cleansing and genocide at that time was almost an academic point (as in meaningless) and, in retrospect, an unhappy one, and maybe with a hint of a more sinister attitude. From being an instrument of international politics, population displacement became a widely used and legitimized method to gain territories under the premise that states must match ethnic borders. However, the ethnic borders in the German mind were a romanticized idea of an historical German Empire. As new lands were conquered, the occupied territories were subjected to a process of Germanization to consolidate and legitimize the increasing size of the German territory. The process, relentlessly bureaucratic, involved compulsory assimilation, resettlements of "pure-blooded" German into the heartland, and massive expulsions of other ethnic groups. The fate of the "expelled" groups who did not have a designated "ancestral homeland" or other place to go was more devastating and fits better the definition of genocide.

Ther's third historical period, from 1944 to 1948, corresponds to the post-WWII order, when as many as 30 million people were relocated. During that period, populations shifted under the purview of the Allied countries, with the intent of disentangling the ethnic borders partly inherited from before WWII by redrawing the boundaries of the states themselves. As a result of these measures, large-scale population transfers took place in Poland, Hungary, Croatia, and Czechoslovakia. In the same wave, large numbers of Germans were also expelled from European countries through a process of de-Germanization. Although the intent was to establish an enduring peace, these movements often took unanticipated turns.

The fourth period defined by the author is much more recent, corresponding to the ethnic cleansing associated with the 1991-99 wars in the former Yugoslavia. This period marks the end of concerted international support for population displacements. For the first time, the term ethnic cleansing enters the public realm conspicuously, in journalism and in academic research. Court-trial records documenting ethnic cleansing provide insights into the dynamics of violence and into the motives of its perpetrators. For the first time, the record gives room, even prominence, to the victims' voices, while the term itself-ethnic cleansing — replaces more anodyne terms from before: population exchange, transfer, and resettlement.

Overall, Ther's book documents how ethnic cleansings (and genocides) were generally well-organized, and often planned by states, throughout the 20th century. The author is very pragmatic in the way he approaches this very serious and demanding subject matter. He describes how the process was and is engineered and administered by states - this may be disturbing to some readers. The process of homogenization might have often begun with some good intentions, but its enactment through ethnic cleansing has exposed the dark side of human nature when fixated by "ideals" such as nation-state and ethnic homogeneity. The book itself is a rich resource for understanding more than a century of population displacements in Europe, and how those population displacements are integral to European history. The author was brave to take on such an ambitious and difficult analysis. Well-written and filled with an impressive amount of information, this book and its notably comprehensive annotated bibliography offer an excellent point of departure to understanding the how and why of ethnic cleansing, and to further exploration of its fraught subject matter. However, this is not a book for the beginner. It demands some background in other histories of their time to fully appreciate its value. 